Article

\title{
Tetrodotoxin and Its Analogues in Cephalothrix cf. simula (Nemertea: Palaeonemertea) from the Sea of Japan (Peter the Great Gulf): Intrabody Distribution and Secretions
}

\author{
Anna E. Vlasenko and Timur Yu. Magarlamov *(D) \\ A.V. Zhirmunsky National Scientific Center of Marine Biology, Far Eastern Branch, Russian Academy of \\ Sciences, 690041 Vladivostok, Russia; avlasenko@imb.dvo.ru \\ * Correspondence: biotimur@yandex.ru; Tel.: +7-914-661-7949
}

Received: 15 November 2020; Accepted: 25 November 2020; Published: 26 November 2020

\begin{abstract}
Some nemertean species from the genus Cephalothrix accumulate tetrodotoxin (TTX) in extremely high concentrations. The current study is the first to provide high-performance liquid chromatography-tandem mass spectrometry (HPLC-MS/MS) data on tetrodotoxin and its analogues (TTXs) profile and concentration in different regions and organs of Cephalothrix cf. simula, and its secretions produced in response to stimulation. Different specimens of $C$. cf. simula possessed 7-11 analogues, including nine previously found in this species and two new for nemerteans-4,9-anhydro-8-epi-5,6,11-trideoxyTTX and 1-hydroxy-8-epi-5,6,11-trideoxyTTX. The study of the toxins' distribution in different regions and organs of nemerteans revealed the same qualitative composition of TTXs throughout the body but differences in the total concentration of the toxins. The total concentration of TTXs was highest in the anterior region of the body and decreased towards the posterior; the ratio of the analogues also differed between regions. The data obtained suggest a pathway of TTXs uptake in C. cf. simula and the role of toxins in the life activity of nemerteans.
\end{abstract}

Keywords: tetrodotoxin; tetrodotoxin analogues; TTX; TTX distribution; Nemertea; Cephalothrix; HPLC-MS/MS

Key Contribution: This is the first report on tetrodotoxin and its analogues' intrabody distribution and composition in secretions of nemertean species.

\section{Introduction}

Tetrodotoxin (TTX) is a potent low-molecular-weight neurotoxin of bacterial origin found in many types of animals and dinoflagellates. It is assumed that carnivores, omnivores, and scavengers can obtain TTX via the food chain or through parasitism and symbiosis [1]. Ribbon worms (Nemertea) are one of these animals that can accumulate TTX in high amounts. Nemertea is a small group (more than 1250 species) of bilateral, coelomic, unsegmented marine worms, most of which are active predators [2]. TTX is mosaically distributed in all three phylogenetic groups of Nemertea-palaeonemertea, pilidiophora, and hoplonemertea. Among palaeonemertea, TTX is found in the genera Cephalothrix [3-8] and Tubulanus [8,9], among pilidiophora, in species of the genera Ramphogordius, Riseriellus [4], Dushia, Micrura [10], Lineus [4,7,9], Cerebratulus, and Kulikovia [8]; among hoplonemertea, in representatives of the Amphiporus [4,7] and Nipponnemertes [7].

Of particular interest are nemerteans of the genus Cephalothrix, which can accumulate extremely high amounts of TTX, which puts them at the same level of toxicity as puffer fishes and blue-ringed 
octopuses $[7,8,11]$. To date, there are several studies on mice showing a strong toxic TTX-associated effect of Cephalothrix simula extracts [5-7]. In subsequent studies, TTX and a number of its analogues were identified in this species [8,11]. The distribution of TTX-like substances in tissues of Cephalothrix sp. was also visualized using an immunohistological study [12]. According to a generally accepted opinion, animals use the toxin for defense, and some species also use it as a weapon [13,14]. Ali and colleagues [3] revealed TTX in the proboscis and secretions of C. simula (named Cephalothrix linearis) released by nemerteans in response to stimulation, which may indicate the use of the toxin both to repel predators and capture prey. However, comprehensive studies showing the distribution of TTX and its analogues (TTXs) in highly toxic nemerteans of the genus Cephalothrix, necessary to understand the transfer and functions of the toxins in animals, have not been performed. In the current work, TTXs were analyzed in different regions and organs of $C$. cf. simula, as well as in secretions released by nemerteans upon stimulation. The profile and concentration of TTX and its analogues in the intestine, body wall, proboscis, and secretions were obtained using high-performance liquid chromatography with tandem mass spectrometry (HPLC-MS/MS), suggesting possible pathways of toxin uptake and transfer in the body of nemerteans and their functions.

\section{Results}

TTXs distribution in the nemertean Cephalothrix cf. simula was investigated in two experiments using HPLC-MS/MS. The first experiment studied the TTXs' profile of the secretions and body of C. cf. simula after stimulation. During the second experiment, TTXs' distributions in the proboscis, different regions of the intestine, and the body wall of $C$. cf. simula were studied.

As a result of the first experiment, seven TTXs were detected in extracts of the body and secretions: TTX, 4-epiTTX, 11-norTTX-6(s)-ol, 4,9-anhydroTTX, 11-deoxyTTX, 5-deoxyTTX, and 5,6,11-trideoxyTTX. As a result of the second experiment, 11 toxins - the seven previously listed and 11-norTTX-6(r)-ol, 11-oxoTTX, 4,9-anhydro-8-epi-5,6,11-trideoxyTTX, and 1-hydroxy-8-epi-5,6,11-trideoxyTTX-were additionally identified (Figure 1, Table 1).
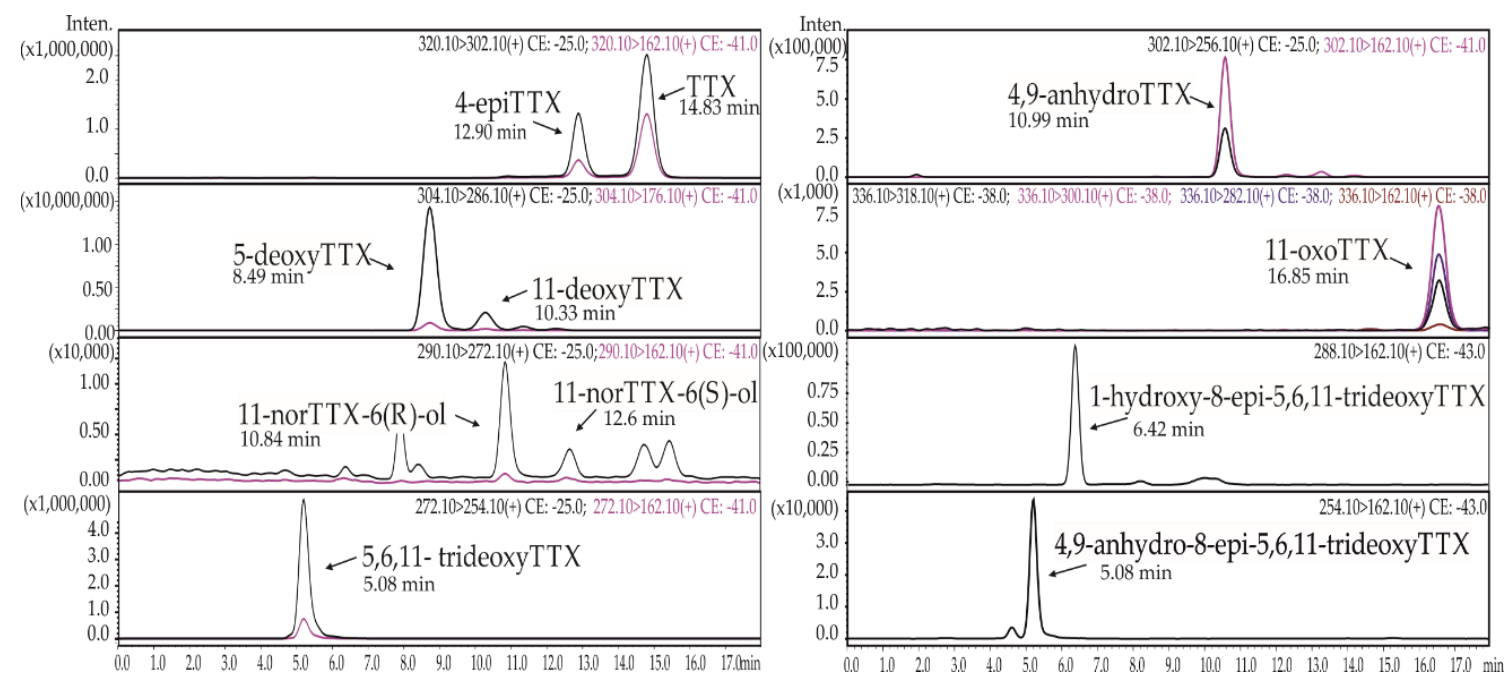

Figure 1. Representative high-performance liquid chromatography-tandem mass spectrometry (HPLC-MS/MS) chromatograms of tetrodotoxin (TTX) and its analogues from Cephalothrix cf. simula extracts obtained from two experiments.

The TTXs' amount in C. cf. simula individuals in both experiments varied from the minimum concentration of $0.13 \mathrm{mg}$ TTXs per gram of tissue (specimen No. 7) to the maximum of $2.14 \mathrm{mg}$ TTXs per gram of tissue (specimen No. 1) (Tables 1 and 2). 
Table 1. Tetrodotoxin (TTX) and its analogues of Cephalothrix cf. simula in the body and secretions.

\begin{tabular}{|c|c|c|c|c|c|c|c|c|c|c|c|}
\hline \multirow[b]{2}{*}{$\begin{array}{c}\text { No. of } \\
\text { Specimen }\end{array}$} & \multirow[b]{2}{*}{ Weight (g) } & \multirow[b]{2}{*}{ Sample } & \multicolumn{9}{|c|}{ TTX and Its Analogues (TTXs) (ng) } \\
\hline & & & TTX & 4-epiTTX & $\begin{array}{l}\text { 11-norTTX- } \\
6(\mathrm{~s}) \text {-ol }\end{array}$ & $\begin{array}{c}4,9- \\
\text { anhydroTTX }\end{array}$ & 11-deoxyTTX & 5-deoxyTTX & $\begin{array}{c}5,6,11- \\
\text { trideoxyTTX }\end{array}$ & $\begin{array}{l}\text { Sum of } \\
\text { TTXs }\end{array}$ & $\begin{array}{c}\text { Total } \\
\text { Amount of } \\
\text { TTXs }\end{array}$ \\
\hline \multirow{2}{*}{1} & \multirow{2}{*}{0.20} & body & $254,758.0$ & $10,641.2$ & 13.2 & 282.0 & 338.5 & 3340.2 & $158,354.4$ & $427,727.5$ & \multirow{2}{*}{$428,596.9$} \\
\hline & & secretions & 613.0 & 29.7 & ND & 4.2 & 1.0 & 83.2 & 138.3 & 869.4 & \\
\hline \multirow{2}{*}{2} & \multirow{2}{*}{0.17} & body & $51,323.0$ & 2137.1 & 6.2 & 91.9 & 94.0 & $11,573.8$ & $127,065.6$ & $192,291.6$ & \multirow{2}{*}{$193,059.9$} \\
\hline & & secretions & 369.2 & 25.0 & 2.2 & 5.0 & 1.0 & 165.7 & 200.2 & 768.3 & \\
\hline \multirow[b]{2}{*}{3} & \multirow{2}{*}{0.25} & body & $53,233.0$ & 1500.4 & ND & 329.1 & 542.4 & 4311.5 & $87,096.5$ & $147,013.0$ & \multirow{2}{*}{$149,080.5$} \\
\hline & & secretions & 1076.1 & 240.2 & ND & 58.7 & 5.1 & 265.0 & 422.5 & 2067.6 & \\
\hline \multirow{2}{*}{4} & \multirow{2}{*}{0.30} & body & $45,345.0$ & 1813.3 & ND & 467.5 & 1334.7 & $20,870.9$ & $28,268.8$ & $98,100.2$ & \multirow{2}{*}{$98,767.5$} \\
\hline & & secretions & 308.6 & 69.6 & ND & 44.0 & 4.5 & 148.5 & 92.1 & 667.3 & \\
\hline
\end{tabular}


Table 2. Tetrodotoxin (TTX) and its analogues in different regions of Cephalothrix cf. simula.

\begin{tabular}{|c|c|c|c|c|c|c|c|c|c|c|c|c|c|c|c|c|c|}
\hline \multirow[b]{2}{*}{$\begin{array}{l}\text { No. of } \\
\text { Specimen }\end{array}$} & \multirow[b]{2}{*}{ Weight $(g)$} & \multirow[b]{2}{*}{ Organ } & \multirow[b]{2}{*}{ Region } & \multicolumn{14}{|c|}{ TTX and Its Analogues (TTXs) (ng) } \\
\hline & & & & TTX & 4-epiTTX & $\underset{\substack{11-\text { norTTX } \\
-6(\mathrm{~s})-\mathrm{ol}}}{2}$ & $\underset{-6(r)-01}{11-n o r T T X}$ & 4,9-anhydroTTX & 11-deoxyTTX & 5-deoxyTTX & $\begin{array}{c}5,6,11- \\
\text { trideoxyTTX }\end{array}$ & 11-oxoTTX & $\begin{array}{c}4,9-\text { anhydro } \\
\text {-8-epi-5,6,11- } \\
\text { trideoxyTTX } \\
\end{array}$ & \begin{tabular}{|c|} 
1-hydroxy- \\
8-epi-5,6,11 \\
-trideoxyTTX \\
\end{tabular} & $\begin{array}{l}\text { Sum of } \\
\text { TTXs }\end{array}$ & $\begin{array}{l}\text { Sum of TTXs } \\
\text { in the Organ }\end{array}$ & $\begin{array}{r}\text { Total } \\
\text { Amoun } \\
\text { of TTX }\end{array}$ \\
\hline \multirow{7}{*}{5} & \multirow{7}{*}{0.17} & \multirow{3}{*}{ Intestine } & Anterior & 9608.3 & 539.8 & 9.4 & 42.8 & 47.4 & 86.6 & 3131.7 & 3487.5 & $<\mathrm{LOQ}$ & 9.9 & 5.0 & $16,968.4$ & \multirow{3}{*}{$19,954.5$} & \multirow{7}{*}{29,012} \\
\hline & & & $\begin{array}{l}\text { Middle } \\
\text { Poterion }\end{array}$ & 561.3 & 53.6 & 0.7 & 4.6 & 5.9 & 37.1 & 380.6 & 308.5 & $<\mathrm{LOQ}$ & 1.0 & 0.6 & 1354.9 & & \\
\hline & & & Posterior & 582.8 & 93.0 & 0.7 & 2.4 & 8.6 & 6.1 & 621.7 & 315.6 & $<\mathrm{LOQ}$ & 0.6 & 0.7 & 1632.2 & & \\
\hline & & \multirow{3}{*}{ Body wall } & Anterior & 714.5 & 42.5 & 0.7 & 3.5 & 4.0 & 6.6 & 257.5 & 204.1 & $<\mathrm{LoQ}$ & 0.9 & 0.4 & 1234.7 & \multirow{3}{*}{2698.9} & \\
\hline & & & Middle & 491.9 & 44.0 & 0.4 & 3.2 & 4.7 & 12.4 & 337.4 & 239.5 & $<$ LoQ & 0.9 & 0.6 & 1135.0 & & \\
\hline & & & Posterior & 122.3 & 15.5 & 0.1 & 0.3 & 1.9 & 1.7 & 138.5 & 48.3 & $<$ LoQ & 0.3 & 0.3 & 329.2 & & \\
\hline & & Proboscis & & 2534.6 & 493.4 & 48.2 & 31.4 & 35.9 & 34.9 & 1992.4 & 1177.9 & 2.0 & 4.3 & 4.2 & 6359.2 & 6359.2 & \\
\hline \multirow{6}{*}{6} & \multirow{6}{*}{0.07} & \multirow{3}{*}{ Intestine } & Anterior & 1342.1 & 15.2 & 0.4 & 0.8 & 3.2 & 12.5 & 194.1 & 627.3 & ND & 1.5 & 0.2 & 2197.3 & \multirow{3}{*}{4395.2} & \multirow{6}{*}{$15,190.3$} \\
\hline & & & Middle & 873.9 & $\begin{array}{l}18.4 \\
0.4\end{array}$ & ND & 0.7 & 1.6 & 9.6 & 142.8 & 563.9 & ND & 1.1 & 0.3 & $\begin{array}{l}1612.3 \\
5856\end{array}$ & & \\
\hline & & & Posterior & 301.8 & 9.1 & 0.1 & 0.3 & 1.0 & 9.0 & 83.8 & 179.9 & ND & 0.4 & 0.2 & 585.6 & & \\
\hline & & \multirow[b]{2}{*}{ Body wall } & Anterior & 4134.5 & 47.7 & 1.0 & ND & 6.4 & 6.0 & 358.3 & 1372.4 & ND & 4.1 & $\mathrm{ND}$ & 5930.4 & \multirow[b]{2}{*}{9370.1} & \\
\hline & & & $\begin{array}{l}\text { Middle } \\
\text { Posterior }\end{array}$ & $\begin{array}{l}1112.0 \\
630.7\end{array}$ & $\begin{array}{l}10.7 \\
10.0\end{array}$ & $\begin{array}{l}0.2 \\
\text { ND }\end{array}$ & $\begin{array}{l}0.8 \\
0.7\end{array}$ & $\begin{array}{l}2.0 \\
2.3\end{array}$ & $\begin{array}{l}3.0 \\
11.6\end{array}$ & $\begin{array}{l}173.1 \\
189.0\end{array}$ & $\begin{array}{l}724.0 \\
546.8\end{array}$ & $\begin{array}{l}\mathrm{ND} \\
\mathrm{ND}\end{array}$ & $\begin{array}{l}2.2 \\
1.5\end{array}$ & $\begin{array}{l}0.3 \\
0.8\end{array}$ & $\begin{array}{l}2028.3 \\
1411.4\end{array}$ & & \\
\hline & & Proboscis & & 900.0 & 9.4 & 2.9 & 1.5 & 1.6 & 3.2 & 115.2 & 389.8 & ND & 1.2 & 0.2 & 1425.0 & 1425.0 & \\
\hline \multirow{7}{*}{7} & \multirow{7}{*}{0.10} & \multirow{3}{*}{ Intestine } & Anterior & 2836.2 & 42.0 & 1.1 & 3.7 & 9.6 & 19.5 & 1013.6 & 978.6 & ND & 3.2 & 0.5 & 4908.0 & \multirow{3}{*}{7453.9} & \multirow{7}{*}{$13,065.2$} \\
\hline & & & Middle & 1038.7 & 19.4 & 0.8 & 1.7 & 6.0 & 9.2 & 490.9 & 489.2 & ND & 1.7 & 0.4 & 2058.0 & & \\
\hline & & & Posterior & 186.7 & 8.5 & 0.1 & 0.5 & 1.8 & 2.0 & 175.7 & 111.8 & $\mathrm{ND}$ & 0.5 & 0.3 & 487.9 & & \\
\hline & & \multirow{3}{*}{ Body wall } & Anterior & 2906.6 & 24.7 & 1.8 & 2.6 & 5.9 & 3.5 & 438.1 & 463.9 & ND & 1.8 & 0.3 & 3849.2 & \multirow{3}{*}{4730.8} & \\
\hline & & & Middle & 331.2 & 8.9 & 0.1 & 0.4 & 1.3 & 0.5 & 131.1 & 122.9 & ND & 0.5 & 0.1 & 597.0 & & \\
\hline & & & Posterior & 113.5 & 4.6 & 0.1 & 0.3 & 1.0 & 0.4 & 98.2 & 66.0 & ND & 0.3 & 0.2 & 284.6 & & \\
\hline & & Proboscis & & 516.1 & 7.5 & 1.9 & 0.8 & 1.2 & 1.3 & 89.2 & 261.6 & ND & 0.9 & $\mathrm{ND}$ & 880.5 & 880.5 & \\
\hline
\end{tabular}

ND: not detected; LoQ: limit of quantification. 


\subsection{TTXs Secretion by Cephalothrix cf. simula}

The percentage of toxins excreted by animals during stimulation with an electric current compared to the total concentration of body and secretions toxins varied from $0.2 \%$ in specimen No. 1 to $1.4 \%$ in specimen No. 3 (Table 1).

In extracts from both the body and the secretions of specimens No. 1 and No. 3, the predominant toxins were TTX and 5,6,11-trideoxyTTX. They comprised more than $72 \%$ of the total amount of TTXs. At the same time, in extracts from No. 2 and No. 4, a significant contribution was made by the third analogue, 5-deoxyTTX, giving more than $82 \%$ of all TTXs in total with TTX and 5,6,11-trideoxyTTX. In body extracts of individuals No. 2 and No. 3, the predominant toxin was 5,6,11-trideoxyTTX at $66.1 \%$ and $59.2 \%$, respectively. In extracts of the body and secretions of specimens No. 1 and No. 4 , TTX was the predominant toxin at $46.2 \%$ and $70.5 \%$, respectively.

The percentage of TTX and its analogues varied both in the body and secretions. Thus, the content of TTX in the body ranged from $26.7 \%$ to $59.6 \%$, and in the secretions it reached $46.2 \%-70.5 \%$. The contents of some TTXs-4-epiTTX, 4,9-anhydroTTX, and 5-deoxyTTX-in the extracts also differed and were relatively higher in secretions compared to those in the body. The content of 4-epiTTX in the body extracts ranged from $1.0 \%$ to $2.5 \%$, and the content in the secretions ranged from $3.3 \%$ to $11.6 \%$; the proportion of 4,9 -anhydroTTX ranged from $0.05 \%$ to $0.47 \%$ in the body, and the proportion in the secretions ranged from $0.65 \%$ to $6.60 \%$; the proportion of 5 -deoxyTTX ranged from $0.8 \%$ to $2.9 \%$ in the body and from $9.6 \%$ to $22.3 \%$ in secretions. The content of 5,6,11-trideoxyTTX was lower in secretions compared to the body: $28.8 \%-66.1 \%$ in the body versus $13.8 \%-26.1 \%$ in the secretions (Figure 2).

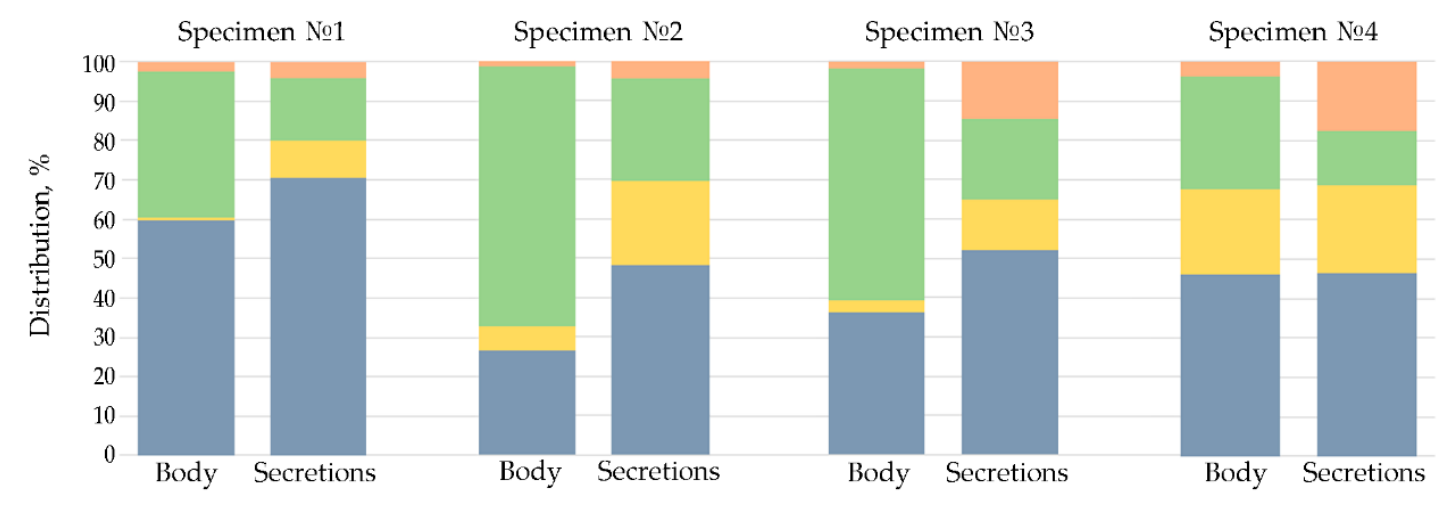

TTX 5-deoxyTTX 5,6,11-trideoxyTTX Others (4-epiTTX, 11-nor-6(s)-ol, 4,9-anhydroTTX, 11-deoxyTTX)

Figure 2. Proportion of tetrodotoxin (TTX) and its analogues in the body and secretions of Cephalothrix cf. simula.

\subsection{Distribution of TTXs in the Body of Cephalothrix cf. simula}

The major toxins of the intestine, body wall, and proboscis samples of three $C$. cf. simula specimens were TTX, 5-deoxyTTX and 5,6,11-trideoxyTTX, which together accounted for $93.9 \%-98.6 \%$ of all TTX analogues. The minor toxins were 4-epiTTX, 11-norTTX-6 (S)-ol, 11-norTTX-6 (R)-ol, 4,9-anhydroTTX, 11-deoxyTTX, 11-oxoTTX, 4,9-anhydro-8-epi-5,6,11-trideoxyTTX, and 1-hydroxy-8-epi-5,6,11-trideoxyTTX; the minor toxins' combined amount accounted for $1.4 \%-6.1 \%$ (Table 2).

The absolute amount of TTXs in different organs varied greatly and differed several-fold between some specimens. Thus, the ratios of TTXs in the intestine, body wall, and proboscis for specimens No. 5, No. 6, and No. 7 were 15:2:5, 6:13:2, and 17:11:2, respectively. It can be seen from the ratio that the lowest concentrations of TTXs were found in the proboscises of specimens No. 6 and No. 7, and the body wall of specimen No. 1. The highest concentrations of TTXs were found in the intestines of specimens No. 1 and No. 3 and in the body wall of specimen No. 2 (Figure 3). 

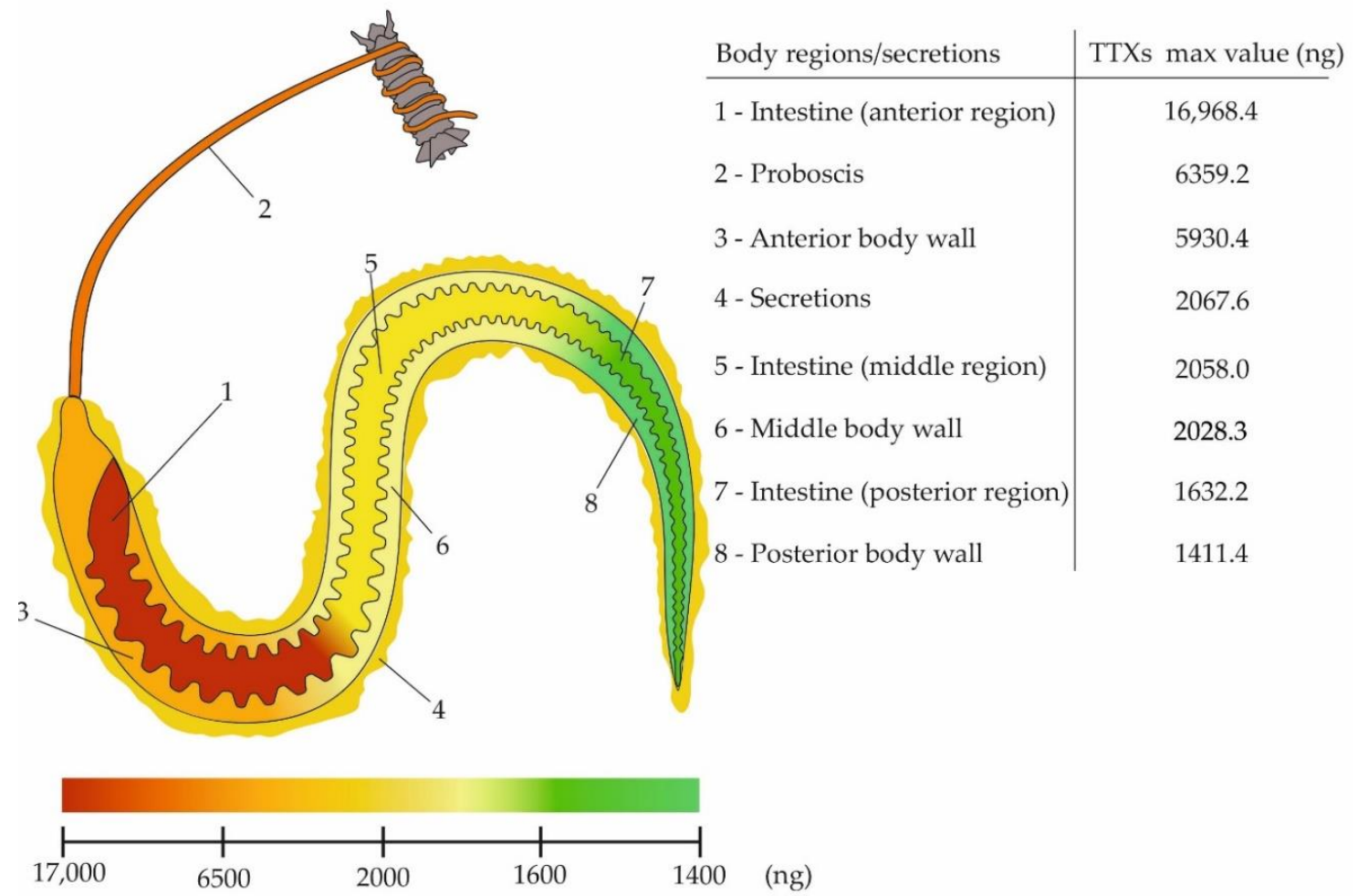

Figure 3. Schematic illustration of the maximum levels (ng) of tetrodotoxin and its analogues (TTXs) in Cephalothrix cf. simula.

TTXs analysis in the body of nemerteans (body wall + intestine) showed that body toxins in specimens No. 5, No. 6, and No. 7 were located mainly in the anterior region: $80.4 \%, 59.0 \%$, and $71.8 \%$, respectively. The remaining body toxins in specimens No. 5, No. 6, and No. 7 were distributed between the middle and posterior regions; the contents of TTXs in the middle region were 1.25, 1.8, and 3.4 times higher, respectively, than those in the posterior region (Table 2).

Distributions of major TTXs in the anterior, middle, and posterior regions of $C$. cf. simula body were different for each analogue. The largest amount of TTX was in the anterior region in specimens No. 5, No. 6, and No. 7-56.7\%, 67.4\%, and 65.6\%, respectively, while percentages in the posterior region decreased by 1.4-1.7 times and amounted to $35.9 \%, 46.7 \%$, and $38.9 \%$, respectively. 5-deoxyTTX was mostly widespread in the posterior region of all specimens, where its content was 2-2.1 times higher than that in the anterior region. The content of 5,6,11-trideoxyTTX was practically equal in the middle and posterior regions of specimens No. 6 and No. 7 and was 1.4-1.5 times higher than that in the anterior region of the same specimen. In specimen No. 5 , the content of this analogue in all sections was approximately the same (Table 2).

For minor TTXs, no large differences were found in the contents for different regions; however, in the posterior region of nemerteans, the amounts of some toxins-4-epiTTX, 4,9-anhydroTTX, and 1-hydroxy-8-epi-5,6,11-trideoxyTTX-were higher compared to that in the anterior and middle regions; conversely, the proportion of 11-norTTX-6 (S)-ol was less (Table 2).

The contribution of proboscis toxins to the total toxins of the organism varied greatly between different specimens and amounted to $21.9 \%, 9.4 \%$, and $6.7 \%$ of total TTXs for specimens No. 5, No. 6 and No. 7, respectively. In the proboscis of all three specimens, major toxins were present at the same levels as in the body; the sum of TTX, 5-deoxyTTX, and 5,6,11-trideoxyTTX accounted for $89.7 \%-98.6 \%$. The most represented toxin was TTX-38.9\%-63.2\% of all TTXs. Among the minor analogues, 11-norTTX-6 (S)-ol can be distinguished; in all specimens, its amount in the proboscis was higher than in each region of the intestine and body wall. In the proboscis of specimen No. 5, 11-oxoTTX was found at an order of magnitude higher than in the body (Table 2). 


\section{Discussion}

An extremely high amount of toxins was shown for nemertean species from the genus Cephalothrix. The content of TTXs in individuals of Cephalothrix simula (named Cephalothrix linearis) collected from the intertidal zone in Shimoda (Shizuoka prefecture, Japan) reached 23,000 MU/g [3], and the content of TTXs in Cephalothrix simula individuals caught in the Hiroshima Bay (Japan) reached 25,590 MU/g [6,7]; these are equivalent to the concentrations of 4094.0-4555.0 $\mu \mathrm{g} / \mathrm{g}$ TTX, respectively. According to Asakawa et al. [7], approximately $80 \%$ of C. simula collected in Hiroshima Bay in 1998-2005 were "extremely toxic" - their toxicity was higher than $1000 \mathrm{MU} / \mathrm{g}(178 \mu \mathrm{g} / \mathrm{g})($ according to the toxicity classification established by the Ministry of Health, Labor and Welfare of Japan). In the current work, C. cf. simula, belonging to the group of species Cephalothrix simula s. 1, was investigated [15]. The concentration of TTXs in nemerteans varied from 133.3 (No. 7) to $2143 \mu \mathrm{g} / \mathrm{g}$ body (No. 1), while five out of seven examined individuals could be classified as "extremely toxic", as their TTXs concentration was above $178 \mu \mathrm{g} / \mathrm{g}$. Asakawa et al. [7] reported that species of the genus Cephalothrix from Qingdao (China) were less toxic than Japanese species. Combined samples of $C$. simula ( $=C$. cf. simula) individuals collected from the Peter the Great Gulf (the Sea of Japan) earlier had a total concentration of TTXs at 66.8 [8] and $23.6 \mu \mathrm{g} / \mathrm{g}$ [16]. An individual of C. simula collected for the first time along the England coast had a total TTXs concentration of $54.3 \mu \mathrm{g} / \mathrm{g}$ [11]. The high toxicity of nemerteans from the coastal waters of Japan is likely associated with the ecological characteristics of the habitat needed to be clarified.

In some TTX-bearing nemertean species, along with TTX, analogues were also found. In most of the species, including Amphiporus sp., Malacobdella japonica, Nipponnemertes punctatula, Lineus alborostratus (=Kulikovia alborostrata), Lineus fuscoviridis, and Lineus torquatus, only equilibrium TTX analogues-4-epiTTX and 4,9-anhydroTTX-were found [17]. However, nonequilibrium analogues were also found in some nemertean species: 5-deoxyTTX, 11-deoxyTTX, and 5,6,11trideoxyTTX were detected in Kulikovia manchenkoi [8] and 11-norTTX-6 (S)-ol and 5,11dideoxyTTX were detected in Yininemertes pratensis [18]. Previously in nemerteans from the Cephalothrix simula s. 1 group, the nonequilibrium analogues 5-deoxyTTX, 11-deoxyTTX, 5,6,11trideoxyTTX [16], 11-norTTX-6(S)-ol, 11-norTTX-6(R)-ol [8], 6,11-dideoxyTTX, 11-oxoTTX, 4,9-anhydro -5,6,11-trideoxyTTX, and 4,9-anhydro-11-oxoTTX [11] were previously found, along with TTX and its equilibrium analogues. Thus, in addition to TTX, 12 analogues belonging to all four families of TTX analogues were found in nemerteans: 1) equilibrium TTX analogues-4-epiTTX and 4,9-anhydroTTX; 2) deoxy analogues-5-deoxyTTX, 11-deoxyTTX, 5,6,11-trideoxyTTX, 6,11dideoxyTTX, 5,11-dideoxyTTX, 4,9-anhydro-5,6,11-trideoxyTTX, and 4,9-anhydro-11-oxoTTX; 3) analogues with a removed methylene group at C-11-11-norTTX-6 (S)-ol and 11-norTTX-6 (R)-ol; 4) 11- $\mathrm{CH}_{2} \mathrm{OH}$ oxidized analogue-11-oxoTTX.

In the present study, different individuals of $C$. cf. simula were shown to possess 7-11 analogues, including nine already found in this species and two TTX analogues that were new for nemerteans-4,9-anhydro-8-epi-5,6,11-trideoxyTTX and 1-hydroxy-8-epi-5,6,11-trideoxyTTX. For three years, our research group has been studying the qualitative and quantitative composition of TTXs of the nemertean C. simula (=C. cf. simula) from Spokoinaya Bay, Peter the Great Gulf, Sea of Japan. In the work of 2018, more than $94 \%$ of all TTXs in the extract of $C$. simula (=C. cf. simula) comprised TTX, 5-deoxyTTX, and 5,6,11-trideoxyTTX, with a predominance of 5,6,11-trideoxyTTX (39.9\%) [8]. In the nemertean caught in 2019, the proportion of toxins differed: the most represented TTX analogue was 4-epiTTX (46.0\%), followed by TTX (31.8\%) and 5,6,11-trideoxyTTX (20.1\%) [16]. In nemerteans studied in the current work, TTX, 5-deoxyTTX, and 5,6,11-trideoxyTTX accounted for, in total, 93.9\%-98.6\% of all TTX analogues. 5,6,11-trideoxyTTX was the predominant toxin in individuals No. 2 and No. $3(66.1 \%$ and $59.2 \%)$; TTX prevailed in the remaining nemerteans $(46.2 \%-70.5 \%)$. In the specimen of $C$. simula studied by Turner and colleagues [11], the amount of TTX was $64 \%$, the second was 6,11-dideoxyTTX (21\%), which was not found in the current study, and the sum of 5-deoxyTTX (11-deoxyTTX) and 5,6,11-trideoxyTTX accounted for 9.9\%. At the same time, 11-oxoTTX accounted 
for $5 \%$, while in the current study, this analogue exceeded the limit of quantification (LoQ) only in the proboscis of specimen No. 5 , and its amount was $0.03 \%$ of the total TTXs of the animal. Data obtained for Cephalothrix simula s. 1. species do not show the obvious regularities in the qualitative and quantitative changes in the composition of TTX and its analogues. A correlation between the qualitative composition of toxins in foods and the composition of toxins in animals has been shown in several works. For example, feeding octopuses Octopus vulgaris with mollusks containing paralytic shellfish toxins, a group of low-molecular-weight guanidine toxins, resulted in the same prevalence of these toxins in both predator and prey [19]. However, in experiments studying the consumption of mollusks containing TTX (without analogues) by a puffer fish, Takifugu obscurus, TTX analogues were detected in the body of the fish, which might indicate possible biotransformation of toxins [20]. In the case of the nemerteans $C$. cf. simula, identical qualitative compositions of toxins in the intestine and body wall may indicate that TTX analogues appear due to food uptake, not as a result of TTX conversion. To test this assumption, $C$. cf. simula food item identification with subsequent analysis of TTX and its analogues are planned in the future.

According to the prevailing theory, TTX is produced by bacteria and transfers to animals capable of accumulating it. Animals at high trophic levels can accumulate TTX in high amounts via the food chain [1]. Thus, numerous feeding experiments on puffer fish [20], gill slug Pleurobranchaea maculata [21], and sea gastropod Neptunea arthritica [22] with TTX-containing items have shown the ability of animals to accumulate TTX from food. TTX uptake by nemerteans can also be a result of absorbing the toxin along with food items. Tanu et al. [12] investigated TTX localization in the body of nemertean Cephalothrix sp. by immunohistochemistry and showed that the only TTX-positive structures in the digestive tract were phagosomes of ciliated or "columnar" (according to Gibson, [23]) cells. The authors concluded that the main mechanism of TTX uptake into the nemertean body is the absorption of toxins along with the victim's tissues through the phagocytic activity of ciliary cells. We confirmed by HPLC-MS/MS that the intestines of the studied nemerteans contained high amounts of TTXs in relation to the total content of TTX and its analogues in a nemertean's body. We should also mention that the anterior intestine contained up to $85 \%$ of all intestinal toxins (Table 2). The inhomogeneous distribution of toxins in the digestive tract of $C$. cf. simula can result from different aspects in the digestion process. The process of food digestion in nemerteans with a macrophage type of nutrition, which include the genus Cephalothrix, can be divided into two phases of intracellular digestion which occur simultaneously in real conditions [23]. The first phase takes place in the foregut cavity, where the tissue of the victim is destroyed by proteolysis in an acidic environment ( $\mathrm{pH}$ is approximately 5.0). The second phase involves intracellular digestion of small particles by ciliary cells located throughout the digestive tract. Thus, a high concentration of TTXs in the anterior region of the digestive tract of C. cf. simula can arise due to the relatively high local concentration of substances released from the food object during the destruction of its tissues in the foregut cavity, as well as due to the action of an acidic environment that increases TTXs solubility. Another issue is the inhomogeneous distribution of TTX analogues in different regions of the nemertean body. We found that while the content of TTX was highest in the anterior region in comparison to the middle and posterior regions, the amount of 5-deoxyTTX was the highest in the posterior region of all specimens. The content of 5,6,11-trideoxyTTX in the middle and posterior regions of two of the three nemerteans was higher than that in the anterior. It remains unclear whether such specific analogue localization is associated with different toxin absorptions due to differences in physicochemical properties or to the possible existence of an additional TTXs transfer mechanism, selectively acting towards certain analogues. Confirmation of a specific TTX transport mechanism was shown in toxic and conditionally toxic puffer fish in an in vitro experiment which incubated fish liver tissue slices in a toxin solution [24,25]. It was supposed that TTX was transported across the cell membrane of puffer fish liver cells using a carrier-mediated transport system [24].

TTX-bearing animals can use the toxin for defense against predators, for capturing and immobilizing the victim during hunting, and as a carrier of information according to some evidence [13]. 
Animals using TTX in venom accumulate the toxin in the organs involved in food capture and use it to immobilize the prey. In the blue-ringed octopuses, Hapalochlaena lunulata and Hapalochlaena maculosa, the bulk of TTX was found in the posterior salivary glands, a usual tool for producing paralyzing poison [26,27]. In the polyclad flatworm Planocerid sp., a large amount of TTX and 11-norTTX-6(S)-ol is contained in the pharynx and is utilized in the process of hunting [28]. In sea arrowworms, Parasagilta elegans (type Chaetognatha), TTX and its analogues were mainly localized in the head and, according to the authors' assumptions, in the organs responsible for food capture [29]. Ali et al. [3] revealed that high amounts of TTX and its analogues were localized in the proboscis of nemertean C. simula (named C. linearis), a specific organ involved in the process of prey capture. When the proboscis is everted, cells of the glandular epithelium, according to immunohistochemical studies containing TTX-positive tags, appear outside [12,30]. It is known that nemerteans with macrophage-type nutrition, which include $C$. simula, coil their proboscis around the victim in a spiral during hunting, retract the proboscis, bringing the prey closer to the mouth opening, and swallow the prey [31]. The current study found that the proboscis significantly contributes to the overall toxicity of the body. Additionally, more than half of TTXs in the C. cf. simula body were found in the anterior region. According to the data obtained, two possible mechanisms regarding the use of toxins by nemerteans during hunting are suggested: (1) TTX and its analogues, localized in the proboscis, affect the prey, paralyze it, and the nemertean completes the process of killing using TTXs in the foregut; (2) the nemertean kills the victim by TTXs secreted by the front of the body and swallows it without using the proboscis.

Another way animals use TTX is as a defense against predator attacks. It was found that some species of puffer Takifugu, in response to stimulation by electric shock, produced secretions containing large amounts of TTX, which was accompanied by inflating the body as a defensive reaction in response to an attack [32]. TTXs are often found in secretions collected from the skin of some animals (e.g., larvae [33], adults of some puffer fish species [34], and flatworms Planocera multitentaculata [35]), and according to the authors' assumptions, these toxins are used to repel predators. TTX was also found in C. simula (named C. linearis) secretions produced in response to repeated mechanical stimulation for six days [3]. The toxicity of the secretions decreased on the third day and completely disappeared by the last day. In the current study, C. cf. simula secreted from 667.3 to $2067.6 \mathrm{ng}$ of TTXs, which corresponds to approximately 3.8 and $11.6 \mathrm{MU}$, and did not exceed $1.4 \%$ of the sum of all toxins contained in a specimen. Thus, we assumed the amounts of excreted TTX were sufficient to repel and/or kill potential predators, and the decrease in TTX concentrations in the secretions of $C$. simula (named C. linearis), observed by Ali et al. [3], could be explained by the low rate of TTX recovery in the skin of nemerteans upon repeated stimulation. However, this assumption needs to be verified. Nevertheless, Kajihara et al. [15] showed that $C$. simula could be consumed by puffer fish Takifugu niphobles resistant to TTX and could be one of the potential sources of the toxin for puffers.

\section{Conclusions}

In the current study, the profile and concentration of TTX and its analogues in the intestine, body wall, and secretions of the nemertean Cephalothrix cf. simula were examined. As a result, the possible ways of TTX adsorption and the functions of toxins in nemerteans were assumed. Food objects are suggested as the source of TTXs in nemerteans, as evidenced by the high concentration of TTXs in the anterior region of the digestive tract of $C$. cf. simula (up to $85 \%$ of the body TTXs), probably due to the higher release of toxins from the food object as a result of lysis. At the same time, identical qualitative toxin compositions in the intestine and the body wall may indicate the uptake of TTX analogues with food, not as a result of TTX conversion. The ratio of toxins between different regions of the nemertean intestine varied. However, the topic of whether unequal analogues localization is associated with different absorptions of toxins, due to their physicochemical properties or with the possible existence of an additional TTXs transfer mechanism that selectively acts towards certain analogues, remains to be studied. The significant contribution of the proboscis and anterior 
intestine to the overall TTXs of $C$. cf. simula may indicate that the toxins are utilized by nemerteans in hunting and consuming prey. It was also revealed that the amount of TTXs released by C. cf. simula in secretions did not exceed $1.4 \%$, but that amount was sufficient to repel and/or kill potential predators.

TTXs were found in a number of nemertean species; however, only several Cephalothrix species accumulate it in high enough amounts to be considered "extremely toxic" animals. This feature of nemerteans from the genus Cephalothrix may result from a unique source of toxins, which, most likely, is food objects; however, the role of its own microbiota in TTXs production cannot be neglected [36]. A promising approach to uncover the origin of "extremely toxic" species is to identify their food items using metagenomic analysis, followed by screening the identified objects for the presence of TTX and its analogues, as well as by studying their microbiota [37]. This complex approach can help to identify environmental pathways of TTX and its analogues in the ecosystem.

\section{Materials and Methods}

\subsection{Sample Collection}

Cephalothrix cf. simula nemerteans were collected from the rhizoids of the brown alga Saccharina sp. in Spokoynaya Bay (42.7090 N, 133.1809 E), Peter the Great Gulf (Sea of Japan) in July-August 2020. Nemertean species were identified by Dr. Alexey V. Chernyshev, an expert on nemertean zoology. The worms belonged to the Cephalothrix simula s. 1. group and appeared under the name Cephalothrix simula in our early publications. However, recent genetic analysis showed that individuals from the Peter the Great Gulf are not true C. simula [15] and should be cited as C. cf. simula. The worms were kept in seawater aquaria at $17^{\circ} \mathrm{C}$. Some worms were used to collect secretions; for this, nemerteans were placed on a Petri dish with sterile seawater $(1 \mathrm{~mL})$ and were exposed to a short $(2 \mathrm{~s}) 6$-volt electric current pulse. The voltage was chosen to ensure that nemerteans remained active after stimulation. The secretions were collected in $15 \mathrm{~mL}$ tubes, and the resulting samples were frozen at $-20^{\circ} \mathrm{C}$ for further study. After stimulation, samples of worm bodies were frozen at $-20{ }^{\circ} \mathrm{C}$ for further study. A number of $C$. cf. simula nemerteans were used to study TTXs localization; for this, the proboscis was separated from each individual, the body was divided into three equal parts, the body wall and intestines were separated from each part, and all samples were frozen individually at $-20{ }^{\circ} \mathrm{C}$ for further research.

\subsection{TTX and Its Analogues Extraction from the Cephalothrix cf. simula Body and Secretions}

The extracts of $C$. cf. simula were prepared using the following procedure. Samples were homogenized in $0.1 \%$ solution of acetic acid in 70\% methanol (1:10 ratio $(v / v)$ for the body, and 1:3 ratio $(v / v)$ for the secretions extraction) for 5 min using a hand homogenizer. Then, they were ultrasonically treated with an ultrasonic homogenizer HD 2070 (Bandelin Sonopuls, Berlin, Germany) for 10 min (frequency $-20 \mathrm{kHz}$, amplitude $-228 \mu \mathrm{m}$, working cycle $-0.8 \mathrm{~s}$, and interval $-0.2 \mathrm{~s}$ ). The homogenates were centrifuged $\left(14,000 \times \mathrm{g}, 10 \mathrm{~min}, 4^{\circ} \mathrm{C}\right)$, and the supernatants were collected. For body samples, the extraction was repeated twice more $(1: 2$ ratio $(v / v))$, and the supernatants were pooled. The body and secretions extracts were evaporated in a rotor evaporator (Labconco, Kansas City, MO, USA) at $60{ }^{\circ} \mathrm{C}$. The resulting precipitates were dissolved in a $0.1 \%$ aqueous solution of acetic acid at ratios of $1 \mathrm{~mL} / \mathrm{g}$ of nemertean tissue and $100 \mu \mathrm{L} / \mathrm{mL}$ of secretion, and they were filtered through Vivaspin turbo centrifugal concentrators (nominal cutoff molecular weight $5 \mathrm{kDa}$ (Sartorius, Goettingen, Germany)). The resulting samples were stored at $-20^{\circ} \mathrm{C}$ for further research.

The recovery control was made as follows. A solution of $10 \mathrm{ng}$ of TTX in $3 \mathrm{~mL}$ of sterile seawater was prepared, and TTX was extracted according the same procedure as described above for the secretions samples. The recovery was $83.6 \%$. 


\subsection{Analysis of TTX and Its Analogues in the Secretions and Body of Cephalothrix cf. simula}

TTX and its analogues were identified using HPLC-MS/MS. The HPLC system included two pairs of LC-30 pumps, a SIL-30AC autosampler, a CTO-20A thermostat, an SCL-20A system controller, and a triple quadrupole mass spectrometer LCMS-8060 (ShimadzuEuropa, Duisburg, Germany) with electrostatic spray ionization (ESI). Separation was carried out using a SeQuant ZIC HILIC column $(150 \times 2.1 \mathrm{~mm}, 5 \mu \mathrm{m})\left(\right.$ Merck, Darmstadt, Germany) at $40{ }^{\circ} \mathrm{C}$ and a flow rate of $0.2 \mathrm{~mL} / \mathrm{min}$. A binary gradient was used: mobile phase A, ammonia $(5 \mathrm{mM})$ and formic acid $(8 \mathrm{mM})$ in $94: 6$ acetonitrile-water; mobile phase $B$, ammonia $(10 \mathrm{mM})$ and formic acid $(20 \mathrm{mM})$ in water. A gradient profile was used as follows: (a) 0-4.3 $\mathrm{min}, 15 \% \mathrm{~B}$; (b) $4.3-16 \mathrm{~min}, 25 \% \mathrm{~B}$; (c) 16-20 $\mathrm{min}, 50 \% \mathrm{~B}$. The sample volume was $1 \mu \mathrm{L}$. A SeQuant ZIC-HILIC guard column $(20 \times 2.1 \mathrm{~mm}, 5 \mu \mathrm{m})$ (Merck, Darmstadt, Germany) was installed in line before the analytical column through a two-position 6-port valve. At $4.4 \mathrm{~min}$, the valve was switched and guard columns backflashed with isopropanol (4.4-9 $\mathrm{min}$ ) and water (9-15 $\mathrm{min}$ ) at a flow rate of $0.3 \mathrm{~mL} / \mathrm{min}$. At $16 \mathrm{~min}$, the valve was switched back. The mass spectrometer was operated in scan $(m / z 200-1000)$ and multiple reaction monitoring (MRM) modes. The ion source parameters were as follows: interface temperature $-380^{\circ} \mathrm{C}$, desolvation line temperature $-250{ }^{\circ} \mathrm{C}$, nebulizing gas (N2) flow-3 L/min, drying gas (N2) flow-3 L/min, and heating gas (dry air) flow$17 \mathrm{~L} / \mathrm{min}$. Collision energy was $41 \mathrm{eV}$ for precursor transition and $25 \mathrm{eV}$ for fragment transitions. The TTX concentration was calculated using the calibration curve of a standard TTX solution series (Alomone Labs Ltd., Jerusalem, Israel). The toxin detection criteria included a precursor MRM transition peak $\mathrm{S} / \mathrm{N}$ ratio $>3$, relative intensity of the fragment ion peak $>4 \%$, and the order of toxins elution corresponded to that described in Bane et al. [38]. MRM transitions were used to detect TTX analogues as described by Vale [39], Kudo et al. [40], Bane et al. [14], Puilingi et al. [41], and Turner et al. [42]. The concentrations of TTX analogues were calculated following the procedure of Chen et al. [43]. The method was validated using standard TTX solutions in MRM mode. The linearity range was from 0.6 to $100 \mathrm{ng} / \mathrm{mL}$. The recovery range from 1 to $100 \mathrm{ng} / \mathrm{mL}$ of TTX was $98.4 \%$. The LoQ was $0.6 \mathrm{ng} / \mathrm{mL}$. The limit of detection (LoD) was $0.2 \mathrm{ng} / \mathrm{mL}$, and the relative SD was $4.5 \%-14.6 \%$.

Author Contributions: A.E.V. performed the toxin assays from nemertean samples, analyzed the data, and wrote the manuscript. T.Y.M. conceived the study and prepared figures. All authors contributed to collecting the samples and editing the manuscript, and they approved the final draft. All authors have read and agreed to the published version of the manuscript.

Funding: This work was funded by the Russian Foundation for Basic Research (RFBR), Grant no. 18-04-00808 A, and the Ministry of Science and Higher Education of the Russian Federation, agreement no 075-15-2020-796 and Grant no 13.1902.21.0012.

Acknowledgments: We express our sincere thanks to Alexey V. Chernyshev for identifying nemerteans and Daria I. Melnikova for her valuable comments, which significantly contributed to the manuscript's improvement.

Conflicts of Interest: The authors declare no conflict of interest.

\section{References}

1. Noguchi, T.; Arakawa, O.; Takatani, T. TTX accumulation in pufferfish. Comp. Biochem. Physiol. Part D Genom. Proteom. 2006, 1, 145-152. [CrossRef] [PubMed]

2. Kajihara, H.; Chernyshev, A.V.; Sun, S.C.; Sundberg, P.; Crandall, F.B. Checklist of nemertean genera and species published between 1995 and 2007. Species Divers. 2008, 13, 245-274. [CrossRef]

3. Ali, A.E.; Arakawa, O.; Noguchi, T.; Miyazawa, K.; Shida, Y.; Hashimoto, K. Tetrodotoxin and related substances in a ribbon worm Cephalothrix linearis (Nemertean). Toxicon 1990, 28, 1083-1093. [CrossRef]

4. Carroll, S.; McEvoy, E.G.; Gibson, R. The production of tetrodotoxin-like substances by nemertean worms in conjunction with bacteria. J. Exp. Mar. Biol. Ecol. 2003, 288, 51-63. [CrossRef] 
5. Asakawa, M.; Toyoshima, T.; Shida, Y.; Noguchi, T.; Miyazawa, K. Paralytic toxins in a ribbon worm Cephalothrix species (Nemertean) adherent to cultured oysters in Hiroshima Bay, Hiroshima Prefecture, Japan. Toxicon 2000, 38, 763-773. [CrossRef]

6. Asakawa, M.; Toyoshima, T.; Ito, K.; Bessho, K.; Yamaguchi, C.; Tsunetsugu, S.; Shida, Y.; Kajihara, H.; Mawatari, S.F.; Noguchi, T.; et al. Paralytic toxicity in the ribbon worm Cephalothrix species (Nemertea) in Hiroshima Bay, Hiroshima Prefecture, Japan and the isolation of tetrodotoxin as a main component of its toxins. Toxicon 2003, 41, 747-753. [CrossRef]

7. Asakawa, M.; Ito, K.; Kajihara, H. Highly toxic ribbon worm Cephalothrix simula containing tetrodotoxin in Hiroshima Bay, Hiroshima Prefecture, Japan. Toxins 2013, 5, 376-395. [CrossRef]

8. Vlasenko, A.E.; Velansky, P.V.; Chernyshev, A.V.; Kuznetsov, V.G.; Magarlamov, T.Y. Tetrodotoxin and its analogues profile in nemertean species from the Sea of Japan. Toxicon 2018, 156, 48-51. [CrossRef]

9. Miyazawa, K.; Higashiyama, M.; Ito, K.; Noguchi, T.; Arakawa, O.; Shida, Y.; Hashimoto, K. Tetrodotoxin in two species of ribbon worm (Nemertini), Lineus fuscoviridis and Tubulanus punctatus. Toxicon 1988, 26, 867-874. [CrossRef]

10. Campbell, M.E.; Schwartz, M. Immunohistological visualization of tetrodotoxin in Micrura verrili and Dushia atra (Phylum Nemertea). In Proceedings of the National Conferences for Undergraduate Research (NCUR), Salisbury, MD, USA, 10-12 April 2008.

11. Turner, A.D.; Fenwick, D.; Powell, A.; Dhanji-Rapkova, M.; Ford, C.; Hatfield, R.G.; Santos, A.; Martinez-Urtaza, J.; Bean, T.P.; Baker-Austin, C.; et al. New invasive nemertean species (Cephalothrix simula) in England with high levels of tetrodotoxin and a microbiome linked to toxin metabolism. Mar. Drugs 2018, 16, 452. [CrossRef] [PubMed]

12. Tanu, M.B.; Mahmud, Y.; Arakawa, O.; Takatani, T.; Kajihara, H.; Kawatsu, K.; Hamano, Y.; Asakawa, M.; Miyazawa, K.; Noguchi, T. Immunoenzymatic visualization of tetrodotoxin (TTX) in Cephalothrix species (Nemertea: Anopla: Palaeonemertea: Cephalotrichidae) and Planocera reticulata (Platyhelminthes: Turbellaria: Polycladida: Planoceridae). Toxicon 2004, 44, 515-520. [CrossRef] [PubMed]

13. Williams, B.L. Behavioral and chemical ecology of marine organisms with respect to tetrodotoxin. Mar. Drugs 2010, 8, 381-398. [CrossRef] [PubMed]

14. Bane, V.; Lehane, M.; Dikshit, M.; O’Riordan, A.; Furey, A. Tetrodotoxin: Chemistry, toxicity, source, distribution and detection. Toxins 2014, 6, 693-755. [CrossRef] [PubMed]

15. Kajihara, H. Resolving a 200-year-old taxonomic conundrum: Neotype designation for Cephalothrix linearis (Nemertea: Palaeonemertea) based on a topotype from Bergen, Norway. Fauna Nor. 2019, 39, 39-76. [CrossRef]

16. Vlasenko, A.E.; Kuznetsov, V.G.; Petrova, I.Y.; Magarlamov, T.Y. Development of a polyclonal antibody-based indirect competitive ELISA for the determination of tetrodotoxins in marine ribbon worms (NEMERTEA) and its comparison with high performance liquid chromatography-tandem mass spectrometry. Toxicon 2020, 176, 30-33. [CrossRef]

17. Göransson, U.; Jacobsson, E.; Strand, M.; Andersson, H.S. The toxins of nemertean worms. Toxins 2019, 11, 120. [CrossRef]

18. Kwon, Y.S.; Min, S.K.; Yeon, S.J.; Hwang, J.H.; Hong, J.S.; Shin, H.S. Assessment of neuronal cell-based cytotoxicity of neurotoxins from an estuarine nemertean in the Han river estuary. J. Microbiol. Biotechnol. 2017, 27, 725-730. [CrossRef]

19. Lopes, V.M.; Baptista, M.; Repolho, T.; Rosa, R.; Costa, P.R. Uptake, transfer and elimination kinetics of paralytic shellfish toxins in common octopus (Octopus vulgaris). Aquat. Toxicol. 2014, 146, 205-211. [CrossRef]

20. Zhang, X.; Zong, J.; Chen, S.; Li, M.; Lu, Y.; Wang, R.; Xu, H. Accumulation and elimination of tetrodotoxin in the pufferfish Takifugu obscurus by dietary administration of the wild toxic gastropod Nassarius semiplicata. Toxins 2020, 12, 278. [CrossRef]

21. Khor, S.; Wood, S.A.; Salvitti, L.; Taylor, D.I.; Adamson, J.; McNabb, P.; Cary, S.C. Investigating diet as the source of tetrodotoxin in Pleurobranchaea maculata. Mar. Drugs 2014, 12, 1-16. [CrossRef]

22. Sato, S.; Ogata, T.; Kodama, M. Accumulation of tetrodotoxin by marine snail Neptunea arthritica through tetrodotoxin-containing diet. Nippon Suisan Gakkaishi Jpn. Ed. 1991, 57, 315-318. [CrossRef] 
23. Gibson, R. The physiology of digestion in Nemertean worms. Bol. Zool. Biol. Mar. 1972, 29, 55-64. [CrossRef]

24. Matsumoto, T.; Nagashima, Y.; Kusuhara, H.; Sugiyama, Y.; Ishizaki, S.; Shimakura, K.; Shiomi, K. Involvement of carrier-mediated transport system in uptake of tetrodotoxin into liver tissue slices of puffer fish Takifugu rubripes. Toxicon 2007, 50, 173-179. [CrossRef] [PubMed]

25. Nagashima, Y.; Ohta, A.; Yin, X.; Ishizaki, S.; Matsumoto, T.; Doi, H.; Ishibashi, T. Difference in uptake of tetrodotoxin and saxitoxins into liver tissue slices among pufferfish, boxfish and porcupinefish. Mar. Drugs 2018, 16, 17. [CrossRef]

26. Hwang, D.F.; Arakawa, O.; Saito, T.; Noguchi, T.; Simidu, U.; Tsukamoto, K.; Shida, Y.; Hashimoto, K. Tetrodotoxin-producing bacteria from the blue-ringed octopus Octopus maculosus. Mar. Biol. 1989, 100, 327-332. [CrossRef]

27. Asakawa, M.; Matsumoto, T.; Umezaki, K.; Kaneko, K.; Yu, X.; Gomez-Delan, G.; Tomano, S.; Noguchi, T.; Ohtsuka, S. Toxicity and toxin composition of the greater blue-ringed octopus Hapalochlaena lunulata from ishigaki island, Okinawa prefecture, Japan. Toxins 2019, 11, 245. [CrossRef]

28. Ritson-Williams, R.; Yotsu-Yamashita, M.; Paul, V.J. Ecological functions of tetrodotoxin in a deadly polyclad flatworm. Proc. Natl. Acad. Sci. USA 2006, 103, 3176-3179. [CrossRef]

29. Thuesen, E.V.; Kogure, K.; Hashimoto, K.; Nemoto, T. Poison arrowworms: A tetrodotoxin venom in the marine phylum Chaetognatha. J. Exp. Mar. Biol. Ecol. 1988, 116, 249-256. [CrossRef]

30. Magarlamov, T.Y.; Shokur, O.A.; Chernyshev, A.V. Distribution of tetrodotoxin in the ribbon worm Lineus alborostratus. Toxicon 2016, 112, 29-34. [CrossRef]

31. McDermott, J.J.; Roe, P. Food, feeding behavior and feeding ecology of Nemerteans. Am. Zool. 1985, 25, 113-125. [CrossRef]

32. Kodama, M.; Ogata, T.; Sato, S. External secretion of tetrodotoxin from puffer fishes stimulated by electric shock. Mar. Biol. 1985, 87, 199-202. [CrossRef]

33. Itoi, S.; Yoshikawa, S.; Asahina, K.; Suzuki, M.; Ishizuka, K.; Takimoto, N.; Mitsuoka, R.; Yokoyama, N.; Detake, A.; Takayanagi, C.; et al. Larval pufferfish protected by maternal tetrodotoxin. Toxicon 2014, 78, 35-40. [CrossRef] [PubMed]

34. Nuñez-Vázquez, E.J.; Yotsu-Yamashita, M.; Sierra-Beltrán, A.P.; Yasumoto, T.; Ochoa, J.L. Toxicities and distribution of tetrodotoxin in the tissues of puffer fish found in the coast of the Baja California Peninsula, Mexico. Toxicon 2000, 38, 729-734. [CrossRef]

35. Miyazawa, K.; Jeon, J.K.; Noguchi, T.; Ito, K.; Hashimoto, K. Distribution of tetrodotoxin in the tissues of the flatworm Planocera multitentaculata (Platyhelminthes). Toxicon 1987, 25, 975-980. [CrossRef]

36. Kajihara, H.; Sun, S.C.; Chernyshev, A.V.; Chen, H.X.; Ito, K.; Asakawa, M.; Maslakova, S.A.; Norenburg, J.L.; Strand, M.; Sundberg, P.; et al. Taxonomic identity of a tetrodotoxin-accumulating ribbon-worm Cephalothrix simula (Nemertea: Palaeonemertea): A species artificially introduced from the pacific to Europe. Zool. Sci. 2013, 30, 985-997. [CrossRef]

37. Magarlamov, T.Y.; Melnikova, D.I.; Chernyshev, A.V. Tetrodotoxin-producing bacteria: Detection, distribution and migration of the toxin in aquatic systems. Toxins 2017, 9, 166. [CrossRef]

38. Bane, V.; Brosnan, B.; Barnes, P.; Lehane, M.; Furey, A. High-resolution mass spectrometry analysis of tetrodotoxin (TTX) and its analogues in puffer fish and shellfish. Food Addit. Contam. Part A 2016, 33, 1468-1489. [CrossRef]

39. Vale, P. Complex profiles of hydrophobic paralytic shellfish poisoning compounds in Gymnodinium catenatum identified by liquid chromatography with fluorescence detection and mass spectrometry. J. Chromatogr. A 2008, 1195, 85-93. [CrossRef]

40. Kudo, Y.; Yasumoto, T.; Konoki, K.; Cho, Y.; Yotsu-Yamashita, M. Isolation and structural determination of the first 8-epi-type tetrodotoxin analogs from the newt, Cynops ensicauda popei, and comparison of tetrodotoxin analogs profiles of this newt and the puffer fish, Fugu poecilonotus. Mar. Drugs 2012, 10, 655-667. [CrossRef]

41. Puilingi, C.G.; Kudo, Y.; Cho, Y.; Konoki, K.; Yotsu-Yamashita, M. Tetrodotoxin and its analogues in the pufferfish Arothron hispidus and A. nigropunctatus from the Solomon Islands: A comparison of their toxin profiles with the same species from Okinawa, Japan. Toxins 2015, 7, 3436-3454. [CrossRef] 
42. Turner, A.D.; Boundy, M.J.; Rapkova, M.D. Development and single-laboratory validation of a liquid chromatography tandem mass spectrometry method for quantitation of tetrodotoxin in mussels and oysters. J. AOAC Int. 2017, 100, 1469-1482. [CrossRef] [PubMed]

43. Chen, X.W.; Liu, H.X.; Jin, Y.B.; Li, S.F.; Bi, X.; Chung, S.; Zhang, S.S.; Jiang, Y.Y. Separation, identification and quantification of tetrodotoxin and its analogs by LC-MS without calibration of individual analogs. Toxicon 2011, 57, 938-943. [CrossRef] [PubMed]

Publisher's Note: MDPI stays neutral with regard to jurisdictional claims in published maps and institutional affiliations.

(C) 2020 by the authors. Licensee MDPI, Basel, Switzerland. This article is an open access article distributed under the terms and conditions of the Creative Commons Attribution (CC BY) license (http://creativecommons.org/licenses/by/4.0/). 